\title{
Гу Шии
}

Аннотация. $B$ статье, посвященной одной их актуальньх проблел совреленной методики преподавания русского языка как иностранного (РКИ), рассматривается важность владения стратегияли сльслового чтения. Особое внилание уделяется приелал работы с аутентичнылм текстол историко-культурного содержания в процессе обучении РКИ в китайской аудитории.

Ключевые слова: русский язык как иностранный, слысловое чтение, стратегии сльслового чтения, аутентичный текст, китайские студенты-русистьи, историко-культурные тексты.

STRATEGIES FOR SEMANTIC READING OF AUTHENTIC TEXTS

OF HISTORICAL AND CULTURAL CONTENT IN TEACHING RUSSIAN AS A FOREIGN LANGUAGE

\section{Gu Shii}

Abstract. The article deals with one of the current problems of modern methodology of teaching Russian as a foreign language and considers the importance of mastering semantic reading strategies. Special attention is paid to techniques of working with authentic texts of the historical and cultural context in the process of teaching Russian to Chinese students.

Keywords: Russian as a foreign language, semantic reading, semantic reading strategy, authentic text, Chinese students-specialists in Russian Philology, historical and cultural texts. 
У сложнение геополитической ситуации обусловило более интенсивную интеграцию России и Китая в политической, экономической, социокультурной, образовательной сферах. В современных социокультурных условиях для китайских студентов-русистов приоритетным вопросом является формирование и в дальнейшем повышение уровня коммуникативной компетенции. Недостаточный уровень ее сформированности, безусловно, препятствует профессиональному росту китайских студентов-фрилологов, изучающих русский язык. Богатый лексикон, умение анализировать синтаксические конструкции предложений, умение строить вербальные гипотезы, распространяющиеся на общую структуру текстового материала на русском языке, владение стратегиями чтения, умение «построить высказывание на продуктивном уровне с элементами творчества» [1, с. 145] у китайских студентов-русистов являются признакам высокого уровня их коммуникативной компетенции. Чтобы достичь этой цели, мы предлагаем в процессе обучении РКИ активно использовать один из эффективных видов чтения - смысловое чтение.

Вслед за Э.Г. Азимовым и А.Н. Щукиным мы считаем, что одной из важнейших целей обучения русскому языку как иностранному является «рормирование умения в процессе чтения извлекать информацию из графически зафиксированного текста, что позволяет активно использовать изучаемый язык в дальнейшей речевой деятельности» [2, с. 347]. В процессе чтения происходит декодирование свернутой в знаках информации, заключенной в печатном слове. Цель обучения чтению как виду речевой де- ятельности в методике РКИ заключается не только в понимании обучаемыми главной и детальной информации из текста, умении определить языковой состав исходного текста, но и в умении понимать глубокое содержание и эмоционально-эстетическое значение текста, пробуждении у студентов желания точно и уместно использовать изучаемые слова, устойчивые выражения, широкие историкокультурные знания, свидетельствующие об эрудиции человека, в дальнейшей речевой деятельности. Полагаем, что именно смысловое чтение позволяет әффрективно обучать китайских студентов русскому языку. Уточним это значимое понятие с опорой на достоверные и авторитетные источники. Смысловым чтением является такой вид чтения, который нацелен на понимание читающим смыслового содержания текста. А.А. Леонтьев раскрыл содержание понятия «стратегии смыслового чтения». Вслед за ним мы полагаем, что стратегии смыслового чтения - это различные приемы, используемые студентами для восприятия графически оформленной текстовой информации и ее переработки в личностно-смысловые установки в соответствии с коммуникативно-познавательной задачей. Таким образом, цель смыслового чтения заключается в том, чтобы сформировать у студентов умения воспринимать текст как единое смысловое целое: в результате обучаемые не только будут точно и полно понимать содержание текста, но и смогут практически осмыслить извлеченную информацию и использовать ее в дальнейшей деятельности.

В качестве материалов для организации процесса обучения смысло- 
вому чтению мы рекомендуем использовать аутентичные тексты историко-культурного содержания публицистического стиля и его научно-популярного подстиля. Причем на уровне В1-B2 мы выбрали для работы по РКИ именно аутентичные тексты вместо адаптированных текстов, поскольку естественная языковая среда будет гораздо лучше, чем моделируемая педагогом: «образование речевых навыков и умений происходит быстрее и легче, если процесс овладения языком максимально приближен к реальным условиям общения» [там же, с. 217]. Об этом убедительно пишут E.M. Верещагин и В.Г. Костомаров: в аутентичном тексте «лингвокультурологическая информация представлена не искусственным путем, а извлекает из естественных форм языка» [3, с. 45]. Термин «аутентичный» при переводе с английского языка означает «естественный», аутентичный текстовый материал на русском языке не был изначально предназначен для учебных целей РКИ, а был создан носителем русского языка в реальном речевом общении. В связи с этим в аутентичных текстах содержания многообразная лексика, грамматические фрормы, естественные речевые обороты, разнообразные фоновые знания, богатая социокультурная информация [4, c. 130]. Все это способно помочь китайским студентам-русистам повысить уровень своей коммуникативной компетенции. Такой живой текст с интересными историко-культурными фоновыми знаниями о России дает возможность студентам погружаться в атмосфреру совместного поиска и размышлений» [5, с. 2]. Как отмечалось в работе «Некоторые тенденщии современной методики преподавания РКИ», методика обучения РКИ на современном этапе определяет статус аутентичного текста как важнейшей единицы обучения в учебном процессе [6, с. 48]. Вместе с тем, процесс обучения русскому языку станет еще более интересным и успешным для студентов, если «его построить на материале не только художественных, но и публицистических, учебно-научных, научно-популярных текстов об истории и культуры страны изучаемого языка» [7, с. 749]. В связи с этим мы полагаем, что использование аутентичных текстов научно-популярного стиля историко-культурного содержания в процессе обучении смысловому чтению имеет сегодня особую актуальность.

Э.Г. Азимов и А.Н. Щукин подчеркивают, что педагогам необходимо «рассматривать формирование у обучающих осознания цели чтения в каждом конкретном случае пользования этим видом речевой деятельности, выбор стратегии чтения, соответствующей избранной цели» [2, с. 347]. В связи с этим мы увидели, что применение стратегии смыслового чтения на уроках РКИ способствует лучшему пониманию китайскими студентами прочитанного материала.

В процессе обучении смысловому чтению китайские студенты испытывают ряд субъективных и объективных затруднений, в том числе «фонетических (при чтении вслух), лексических, грамматических, лингвокультурологических» [8, с. 46]. Более того, у китайских студентов-русистов наблюдается еще она проблема смысловой барьер. В «Современном словаре методических терминов и понятий» Э.Г. Азимов и А.Н. Щукин 
дали точное определение значимого термина «смысловой барьер»: «Смысловой барьер - трудности, связанные с пониманием содержания прецедентных текстов. Недопонимание, возникающее между людьми и связанное с тем, что, используя в общении друг с другом одни и те же слова, они вкладывают в них различный смысл» [2, с. 281]. Причиной смыслового барьера по их мнению, могут быть «недостаточный уровень владения языком; невысокий уровень страноведческой и социокультурной компетенции студентов» [там же: с. 282]. Чтобы преодолеть эти трудности, Э.Г. Азимов и А.Н. Щукин рекомендуют педагогам использовать лингвострановедческий комментарий, применять ресурсы справочной литературы (словарей) и т.п.

Стратегии смыслового чтения представляют собой «алгоритм умственных действий и операций в работе с текстом» [7, с. 3]. В связи с этим, правомерно обратить особое внимание на сложные психологические механизмы, работающие во время восприятия письменного текста китайскими студентами: «В процессе чтения читающий как бы постоянно строит гипотезы о дальнейшем изложении» [9, с. 3]. Этот механизм прогнозирования проявляется в двух аспектах: 1) вербальное прогнозирование (построение вербальных гипотез: по первым словам угадывается целое предложение); 2) смысловое прогнозирование (построение гипотез о дальнейших сюжетах, событиях, фрактах). Под вероятностным прогнозированием подразумевается процесс соотнесения внешней информации из текстового материала через сложную психологическую де- ятельность с имеющимися у человека знаниями. Таким образом, в результате его развития коммуникативная компетенция у китайских студентов-русистов повышается.

Рассмотрим подробнее этапы работы с аутентичными текстами в контексте развития механизма прогнозирования. На первом этапе (ознакомительном) работы с аутентичным текстом - до чтения (before watching) задачей педагога будет ввод значимой информации, предтекстовый комментарий, обобщение имеющихся у студентов-русистов знаний по конкретной теме; создание благоприятной психологической атмосферы для пробуждения и поддержания устойчивого интереса к данной теме. На этом этапе целесообразно использовать такие обучающие приемы, как выделение новых слов в тексте, опора на вероятностное прогнозирование, когда студенты могут догадаться о значении слов без словаря. Другие фрормы работы: студенты должны рассказать о том, что они знают о конкретной теме; привести историко-культурные фоновые знания о своей стране, сравнить реалии, которые похожи на русские или отличаются от них.

На втором этапе (продуктивном) работы с аутентичным текстом - во время чтения (while watching) аутентичного текста - китайские студенты-русисты получают значимую коммуникативную информацию из нового текста и размышляют о его содержании. На этом этапе мы рекомендуем использовать следующие приемы обучения: задавать однозначные вопросы (требующие краткого, однословного ответа) и альтернативные вопросы (которые предполагают размышление, умение анализировать, 
привлекать дополнительные знания), выделять ключевые слова, ранжировать абзацы и др.

На третьем этапе (творческом) работы с аутентичным текстом - после чтения (follow up activities) - ocновными задачами являются целостное осмысление и обобщение полученной информации, преобразование ее в иную форму, формирование у каждого из студентов оценочных суждений, своего видения изучаемого материала. Здесь можно применить такие обучающие приемы, как рассказ о первом впечатлении от текста; написание краткого сочинения-миниатюры, беседа на дискуссионный вопрос (уровень владения русским языком - B1-В2).

Приведем пример аутентичного текста научно-популярного стиля историко-культурного содержания из книги «Русские цари». На наш взгляд, предложенный текст полезен для обучения китайских студентов-русистов смысловому чтению:

\section{Текст 1}

Перед смертью Василий III благословил на великое княжение трехлетнего сына Ивана. Но правила государством сначала мать малолетнего великого князя Елена. Этот период сопровождался дворцовыми интригами, борьбой за власть и насилием. В 1538 году в возрасте 35 лет Елена внезапно скончалась. Началось так называемое боярское правление. Аристократические кланы сменяли друг друга, и каждый раз это заканчивалось кровавой расправой и убийствами.

Такое окружение юного государя способствовало развитию в нем подозрительности, мстительности и жестокости. Иван IV обладал острым умом и стратегическим мышлением, владел тонкостями политики и дипломатии, был одним из самых образованных людей своего времени, обладал феноменальной памятью и богословской эрудицией. В тоже время он был человеком вспыльчивым и деспотичным (Антонов Б. В, 2016:6) (107 слов).

\section{Предтекстовое упражнение}

$\mathrm{C}$ опорой на языковое чутье, языковую догадку определите значение следующих слов и словосочетаний без помощи словаря и расскажите, какие слова и словосочетания могут быть использованы для описания характера исторической личности.

Подозрительность, мстительность, жестокость, острый ум, стратегическое мышление, владеть тонкостями политики и дипломатии, феноменальная память, богословская эрудищия, вспыльчивый, деспотичный.

Рассмотрите таблицу, в которой отражены периоды правления великих князей от Ивана III Васильевича до Ивана IV Васильевича (Грозного). Вспомните пройденный материал по китайской истории, расскажите, какая династия управляла Китаем в этот период?

Таблица

\begin{tabular}{|l|c|}
\hline Иван III Васильевич & $1462-1505$ \\
\hline Василий III Иванович & $1505-1533$ \\
\hline Иван IV Васильевич (Грозный) & $1533-1584$ \\
\hline
\end{tabular}

\section{Притекстовое упражнение}

I. Ответьте на вопросы кратко

1. Кого благословил на великое княжение перед смертью Василий III? 
2. Когда началось боярское правление?

3. Чем закончилась борьба между аристократическими кланами?

4. Верно ли, что Иван IV обладал феноменальной памятью и богословской эрудицией?

II. Ответьте на вопросы подобно, развернуто

1. Объясните, почему окружение юного государя Ивана IV Грозного способствовало развитию в нем подозрительности, мстительности и жестокости?

2. Согласны ли вы с тем, что Иван IV был человеком воспитанным и образовательным? Свой ответ аргументируйте.

3. Почему Иван IV являлся одним из самых образованных людей своего времени? Какие таланты у него было? Приведите примеры.

\section{Послетекстовое упражнение}

1. Перескажите (кратко/подобно) главное содержание данного текста. Обратите внимание на следующие ключевые слова и словосочетания:

Благословить, княжение, малолетний, сопровождаться, двориовые интриги, боярское правление, аристократические кланы, кровавая расправа, убийство
2. Есть ли в истории Китая исторический близнец у Ивана IV, который тоже обладал острым умом и стратегическим мышлением, но был человеком вспыльчивым и деспотичным?

Наше обращение к аутентичным текстам историко-культурного содержания вызвано не просто необходимостью иллюстрации языковых явлений. Таким способом мы стремимся повысить интерес у китайских студентов интерес к русскому языку, русской истории и культуре. На наш взгляд, аутентичный историко-культурный материал не только обладает познавательной ценностью, благодаря этому студенты узнают достоверные сведения о русской истории, богатстве русской культуры, о традициях русского народа, но и осознают необходимость получения такой информации, обладающей коммуникативной ценностью, которая побуждает всех китайских студентов говорить порусски и активно использовать при изучении русского языка вербальное вероятностное прогнозирование, в результате чего реализуется принцип устного определения.

\section{СПИСОК ИСТОЧНИКОВ И ЛИТЕРАТУРЫ}

1. Янченко, В.Д., Лю Цянь. Развитие у китайских студентов вербального вероятностного прогнозирования в обучении РКИ // Самарский научный вестник. 2015. № 1. С. 145-147.

2. Азимов, Э.Г., Щукин, А.Н. Современный словарь методических терминов и понятий (теория и практика обучения языкам). М.: Русский язык. Курсы, 2018. 496 с.

3. Верещагин, Е.М., Костомаров, В.Г. Язык и культура: Лингвострановедение и преподавание русского языка как иностранного. М.: Русский язык, 1990. 246 с.

4. Кулибина, Н.В. О тексте как ресурсе обучения речевому общению на практических занятиях по РКИ // Русский язык и литература: проблемы обучения и преподавания в школе и вузе. М., 2009. 440 с.

5. Пяткова, О.Б. Формирование стратегий смыслового чтения текстовой информации у обучающихся // Научно-методический электронный журнал «Концепт». 2017. № 7. URL: http:// e-koncept.ru/2017/170162.htm (дата обращения: 11.05.2019). 
6. Дейкина, А.Д., Янченко, В.Д. Некоторые тенденции современной методики преподавания русского языка как иностранного // Современная коммуникативистика, 2018. № 1. С. 47-51.

7. Янченко, В.Д., Цзи Мин. Роль чтения исторических текстов в развитии когнитивных способностей китайских студентов-русистов // IV Международный педагогический форум «Текст культуры и культура текста». СПб.: Златоуст, 2017. С. 746-750.

8. Янченко, В.Д., Цзи Мин. Способы предупреждения трудностей в процессе обучения чтению китайских студентов // Наука и школа, 2017. № 2. С. 45-52.

9. Шибко, Н.Л. Методика обучения русскому языку как иностранному. Учебник. Минск: БГУ, 2011. $165 \mathrm{c}$.

\section{REFERENGES}

1. Azimov E.G., Sukin A.N. Sovremennyj slovar metodiceskih terminov i ponjatij (teorija i praktika obucenija jazykam). Moscow, 2018, 496 p. (in Russian)

2. Dejkina A.D., Jancenko V.D. Nekotorye tendencii sovremennoj metodiki prepodavanija russkogo jazyka kak inostrannogo, Sovremennaja kommunikativistika, 2018, No. 1, pp. 47-51. (in Russian)

3. Janchenko V.D., Czi Min. "Rol ctenija istoriceskih tekstov v razvitii kognitivnyh sposobnostej kitajskih studentov-rusistov", in: IV Mezdunarodnyj pedagogiceskij forum "Tekst kultury i kultura teksta”, Saint-Petersburg, Zlatoust, 2017, pp. 746-750. (in Russian)

4. Janchenko V.D., Czi Min. Sposoby predupreždenija trudnostej v processe obucenija cteniju kitajskih studentov, Nauka i skola, 2017, No. 2, pp. 45-52. (in Russian)

5. Janchenko V.D., Lju Cjan. Razvitie u kitajskih studentov verbalnogo verojatnostnogo prognozirovanija v obucenii rki, Samarskij naucnyj vestnik, 2015, No. 1, pp. 145-147. (in Russian)

6. Kulibina N.V. "O tekste kak resurse obucenija recevomu obŝeniju na prakticeskih zanjatijah po RKI”, in: Russkij jazyk i literatura: problemy obucenija i prepodavanija v škole i vuze, Moscow, 2009, 440 p. (in Russian)

7. Pjatkova O.B. Formirovanie strategij smyslovogo ctenija tekstovoj informacii u obucajusihsja, Naucno-metodiceskij elektronnyj zurnal "Koncept", 2017, No. 7, available at: http://e-koncept. $\mathrm{ru} / 2017 / 170162 . \mathrm{htm}$. (in Russian)

8. Sibko N.L. Metodika obucenija russkomu jazyku kak inostrannomu. Uchebnik. Minsk, 2011, 165 p. (in Russian)

9. Veresagin E.M., Kostomarov V.G. Jazyk i kultura: Lingvostranovedenie i prepodavanie russkogo jazyka kak inostrannogo. Moscow, 1990, 246 p. (in Russian)

Гу Шии (Китай), аспирант, Московский педагогический государственный университет, gusveta2016@yandex.ru

Gu Shii (China), Post-graduate Student, Moscow Pedagogical State University, gu-sveta2016@ yandex.ru 